\title{
THE EVOLUTION OF OUTBREEDING IN PLANTS
}

\author{
I. THE ANGIOSPERMS \\ LESLIE K. CROWE * \\ Botany School, Oxford University
}

Received 5.ii.64

\section{INTRODUCTION}

IN many species of Angiosperms outbreeding is compulsory. The commonest system to enforce outbreeding is incompatibility. Reviews by East (1940) and Fryxell (1957) show the high frequency and wide distribution of incompatibility systems in the Angiosperm phylum.

In different families, incompatibility systems of six different types are to be found. Yet within the same family and sometimes within closely related families the type of system is constant (table I). From this observation it has been concluded that incompatibility is not only common in the Angiosperms but is also ancient in origin, being at least as old as the families in which it occurs.

The climax of this line of thought is the suggestion that the sudden emergence and supremacy of the Angiosperms was linked with the evolution of incompatibility and the advantages conferred by such an efficient outbreeding system. Whitehouse (I950), the originator of this theory, proposed that incompatibility arose only once in the Angiosperms and that it arose in association with the evolution of the style. In this context the existence of incompatibility in plants other than Angiosperms must be taken into account. It occurs in Algæ (Starr, 1954), Fungi (Whitehouse, I949), Pteridophytes (Wilkie, I956) and Gymnosperms (Piatnitsky, 1934). Some of these groups included leading competitors of the early Angiosperms. It is doubtful, therefore, whether the initial selective advantage of the Angiosperm phylum can be attributed solely to the presence of incompatibility. In addition it is obvious that the style is not an essential feature of these systems. Paradoxically, however, the fact that incompatibility is widespread in lower plants, which vitiates the main arguments on which Whitehouse based his theory, also makes it inherently more likely that the incipient Angiosperms inherited incompatibility from their predecessors. Its continuous evolution would then be more ancient and not less ancient than he supposed.

If incompatibility was already present in the first Angiosperms, it follows, firstly, that many if not all self-compatible species of the present day may have been derived from self-incompatible ancestors. Secondly, the galaxy of existing outbreeding systems may have evolved

* Present address: The Botany Department, The University, Reading, Berks. 
TABLE I

The similarity of outbreeding systems within angiosperm families

\begin{tabular}{|c|c|c|}
\hline $\begin{array}{l}\text { Incompatibility } \\
\text { system }\end{array}$ & Family & Genera \\
\hline \multirow[t]{3}{*}{ HETEROMORPHIC } & PLUMBAGINACE $\not E$ & $\begin{array}{l}\text { Ceratostigma, Limonium, Armeria, Acan- } \\
\text { tholimon, Goniolimon, Limoniastrum. }\end{array}$ \\
\hline & PRIMULACE AE* & Primula, Hottonia, Androsace. \\
\hline & $R U B I A C E A E$ & I 7 Genera (see Darwin, I877). \\
\hline \multirow{3}{*}{$\begin{array}{l}\text { Номомоврніс } \\
\text { Sporophytic } \\
\text { control }\end{array}$} & RUBIACEAE & Galium. \\
\hline & CRUCIFER E & $\begin{array}{l}\text { Iberis, Cardamine, Capsella, Brassica, } \\
\text { Raphanus. }\end{array}$ \\
\hline & COMPOSIT E & Parthenium, Crepis, Cosmos. \\
\hline \multirow{5}{*}{$\begin{array}{l}\text { Номомоврніс } \\
\text { Gametophytic } \\
\text { control. I locus }\end{array}$} & ROSACEAE & Prunus, Malus. \\
\hline & LEGUMINOSE AE & Trifolium (4 species). \\
\hline & ONAGRACE EE & Oenothera ( 7 species). \\
\hline & SCROPHULARIACEAE & $\begin{array}{l}\text { Veronica, Antirrhinum, Nemesia, } \\
\text { Verbascum. }\end{array}$ \\
\hline & SOLANACE $A E$ & Nicotiana, Petunia, Solanium, Lycopersicum. \\
\hline \multirow{2}{*}{$\begin{array}{l}\text { НомомоврHIC } \\
\text { Gametophytic } \\
\text { control. } 2 \text { loci }\end{array}$} & SOLANACE E & Solanum, Physalis. \\
\hline & GRAMINE E & Secale, Festuca, Phalaris. \\
\hline
\end{tabular}

* Cortusa, Cyclamen, Lysimachia and Trientalis are self-incompatible and homomorphic.

from a single primitive type of incompatibility. Three kinds of evidence are required to confirm these possibilities:

(i) evidence of an evolutionary sequence in the outbreeding systems in the Angiosperms,

(ii) evidence of species in the process of transition from one outbreeding system to another and

(iii) evidence of extinct outbreeding systems in self-compatible species.

If such evidence cannot be found then it is more likely that the various outbreeding systems are unrelated and have arisen independently on many separate occasions. This interpretation is preferred by Bateman (1952a) and others.

The data concerning the history of incompatibility and other outbreeding systems developed by the Angiosperms are fragmentary and often blurred by mutation, hybridisation and other past events. However, when all the relevant information is assembled it reveals 
evidence of unsuspected relationships between the different outbreeding systems. The first purpose of this paper is to explore these relationships. The second purpose is to show that the different outbreeding systems in the Angiosperms represent an evolutionary sequence. Finally, these findings will be applied to the wider problem of the age and origin of outbreeding systems in plants as a whole.

\section{DEFINITIONS}

To avoid complex descriptions of the various types of incompatibility in the text, certain abbreviations have been used. These are defined below.

I. Heteromorphic Incompatibility. These systems have the following characteristics in common:-

(i) each mating type is morphologically distinct and can be recognised without breeding tests. Commonly they differ in the relative positions of their stigma(ta) and anthers, i.e. Heterostyly.

(ii) the mating type of the pollen is determined sporophytically.

(iii) dominance between alleles of the incompatibility gene(s) is expressed in both the pollen and style.

(iv) the growth of incompatible pollen tubes is inhibited in the style.

The systems can be controlled by one gene with two alleles, i.e. Dimorphy (type Ia) as in Primula, or they can be controlled by two genes both with two alleles, i.e. Tristyly (type Ib) as in Lythrum.

II. Homomorphic Incompatibility. These systems have the following characteristics in common:-

(i) all mating types are morphologically alike and can be recognised only by breeding tests

(ii) there are numerous mating types

(iii) there are numerous alleles of the incompatibility gene(s).

There are two main classes of homomorphic incompatibility.

Gametophytic Incompatibility. In these systems the mating type of the pollen grains is determined gametophytically. Alleles of the incompatibility gene(s) act individually in the style. Incompatible pollen tubes are inhibited in the style. Gametophytic incompatibility can be controlled by alleles at one locus (type IIa) as in Enothera or by alleles at two loci (type IIb) as in Secale.

Sporophytic Incompatibility. In these systems the mating type of the pollen grains is determined sporophytically. Alleles of the incompatibility gene can express either dominance or individual action in both the male and female organs. Incompatible pollen tubes can be inhibited on the style (type IIc) as in Parthenium or incompatibility may be expressed between gametes after fertilisation, Post-fertilisation Incompatibility (type IId), as in Theobroma.

\section{METHODS}

I have used evidence of various kinds to build a clear picture of the relationships between the different breeding systems. Firstly, the genetic properties of the systems themselves are of prime importance including the number of controlling genes, their structure as revealed by mutation and crossing over, and their morphological and physiological effects. Secondly, the general distribution of the breeding systems and their particular systematic grouping have also been considered.

I have used certain principles in the interpretation of the evidence. These relate to the variation in the times of action of a gene and the irreversibility of the evolutionary change from outbreeding to inbreeding. I have also assumed that evolution in some other directions is irreversible as for instance the change from diploid to polyploid, from distributed to localised chiasmata and from simple gene to supergene. 


\section{THE DISTRIBUTION OF OUTBREEDING SYSTEMS IN THE ANGIOSPERMS}

The distribution of different outbreeding systems amongst the Angiosperms is important. Although the picture is incomplete, certain salient facts emerge which help to decide which systems are recent and secondary in origin and which are ancient and perhaps primary systems.

\section{(i) Dioecy}

Diœcious plants are rare in the Angiosperms. The Yampolskys' (I g22) general survey of the world flora revealed that only 5 per cent. of the genera are completely diœcious while in the British flora, the figure is only 3 per cent. (Lewis, 1942). On the other hand diœey occurs sporadically in about 75 per cent. of all Angiosperm families. It is more common in woody than in herbaceous plants and common in lower rather than advanced orders.

The few families consisting exclusively of diccious members are small families. According to Hutchinson's (1926) classification they are as follows:-

$\begin{array}{llrllll}\text { Number of genera . } & \text {. } & \text { I } & 2 & 3 & 4 & 5 \\ \text { Number of families . } & \text {. } & \text { I } 6 & 5 & 2 & & \text { I }\end{array}$

None of the main centres of development is composed entirely of diœcious types and in fact where diœcy is firmly established, as for instance in the Amentiferæ of Engler, it has evidently stopped the families developing. The condition then is obviously irreversible and ends in an evolutionary blind alley. Such evidence supports the widely held view that the primitive Angiosperms were hermaphrodite. Diœcy must therefore be classified as a secondary and terminal development. It is an experiment which has been repeated on many separate occasions but has never met with more than limited success.

\section{(ii) Gynodiacy}

Occasional male-sterile individuals occur in a wide range of hermaphrodite species but it is seldom that male-sterile plants become established as a permanent feature of a species. Apart from one case in Fuchsia, gynodiœcious species are confined to the more advanced herbaceous orders. Frequently a single gynodiocious species arises in a family which is otherwise entirely hermaphrodite. The Labiateæ is an exception in this respect, having many examples of gynodicecy.

The low frequency and sporadic distribution of this type of outbreeding system suggest that, like diœecy, it is a secondary type which has arisen independently in different groups.

\section{(iii) Heteromorphic incompatibility}

There are fifty-one genera known to include species in which incompatibility is accompanied by heteromorphism (table 2). The 
majority of these were described by Darwin (1877). Only a few examples like Narcissus (Bateman, I 952b), one large assembly in the Plumbaginaceæ (Baker, I954) and some examples in the Connaraceæ (Baker, 1962) have been recorded since.

The Primulaceæ, Rubiaceæ and Plumbaginaceæ between them include more than half of the heteromorphic genera and those are almost exclusively heteromorphic except where polyploidy has upset the system. The remaining examples are scattered amongst fifteen

TABLE 2

Self-incompatible heteromorphic species in the Angiosperms

\begin{tabular}{|c|c|c|}
\hline -Order & Family & Genus \\
\hline Primulales & $\begin{array}{l}\text { PRIMULACEA } \\
P L U M B A G I \mathcal{N} A C E A E\end{array}$ & $\begin{array}{l}\text { Primula, Hottonia, Androsace. } \\
\text { Ceratostigma, Goniolimon, Acantholimon, Limoni- } \\
\text { astrum, Limonium, Armeria. }\end{array}$ \\
\hline Rubiales & $R U B I A C E A$ & I 7 Genera. \\
\hline Guttiferales & HYPERICACEA & Cratoxylon. \\
\hline Malpigiales & HUMARIACEA & Erythroxylon, Sethia. \\
\hline Geraniales & $\begin{array}{l}L I N A C E A \\
O X A L I D A C E A E\end{array}$ & $\begin{array}{l}\text { Linum. } \\
\text { Oxalis, Averrhoa. }\end{array}$ \\
\hline Lythrales & LYTHRACEA & Lythrum, Nesea. \\
\hline Sapindales & CONNARACE $A$ & Agelea, Byrsocarpus, Cnestis, Santaloides. \\
\hline Loganales & $O L E A C E A$ & Forsythia. \\
\hline Gentianales & $\begin{array}{l}\text { GENTIANACEA } \\
P O L E M O \mathcal{N} I A C E \mathscr{F}\end{array}$ & Menyanthes, Villarsia, Limnanthemum. \\
\hline Boraginales & $B O R A G I N A C E A$ & Pulmonaria, Cordia. \\
\hline Lamilæs & $V E R B E \mathcal{N} A C E A$ & Egiphila. \\
\hline Polygonales & POLTGONACEA & Fagopyrum. \\
\hline Thymelæales & THYMELAEACEA & Thymelea. \\
\hline $\begin{array}{l}\text { Rhamnales } \\
\text { Amaryllidales }\end{array}$ & $\begin{array}{l}R H A M \mathcal{N} A C E A \\
A M A R Y L L I D A C E A E\end{array}$ & $\begin{array}{l}\text { Rhamnus. } \\
\text { Narcissus. }\end{array}$ \\
\hline Lilales & PONTEDERIACE E & Pontederia. \\
\hline Saxifragales & $S A X I F R A G A C E A$ & Jepsonia. \\
\hline
\end{tabular}

different families; some arborescent but mostly herbaceous, some monocotyledons but mostly dicotyledons and some in low but mostly in advanced orders. It is concluded, therefore, that heteromorphic incompatibility is a secondary outbreeding system which has arisen on a number of occasions.

\section{(iv) Homomorphic incompatibility}

These outbreeding systems are undoubtedly the most frequent, widespread and successful in the. Angiosperms. They have been reported in sixty-six different families and since they are the least obvious of the outbreeding devices, they may well be present in many more. The examples include arborescent and herbaceous genera, monocotyledons and dicotyledons, and lower as well as advanced orders. These systems are in fact ubiquitous.

So far, four variants of homomorphic incompatibility have been reported. The first two variants (IIa and IIc) are both controlled by 
a single locus and in both incompatibility is expressed in the style. They can be distinguished by the fact that in one of them the mating type of the pollen is determined sporophytically while in the other it is determined gametophytically. The systems have been reported in many dicotyledons but only in one monocotyledon, Tradescantia. The third and fourth variants (IIb and IId) are chiefly characterised by two controlling loci in one case and post-fertilisation incompatibility in the other. These appear to be more common in the monocotyledons.

If there is indeed a primary outbreeding system extant in the Angiosperms then, of the currently recognised types, one of the homomorphic incompatibility systems is the most likely candidate.

\section{RELATIONSHIPS BETWEEN DIFFERENT OUTBREEDING SYSTEMS}

It is in families with two or more outbreeding systems that the search for species in various stages of transition from one system to another is likely to be most successful. It is unusual to encounter two types of homomorphic incompatibility in the same family and therefore the relationships between the four systems in this category are difficult to establish. On the other hand diøecy, gynodiocy and heteromorphic incompatibility are frequently represented in "mixed families". Consequently the relationships of these systems are easier to trace.

The use of heterostyly as a guide in tracing past changes in the breeding system is worthy of special mention. The form and physiology in heterostyles species is determined by two series of alleles which are held together and inherited as two alternate supergenes. Only on rare occasions does crossing-over break up these associations: (Dowrick, 1956). Thus the stability of the supergenes is such that the morphological differences under their control may persist even though the elements controlling incompatibility itself undergo change.

\section{(i) The origins of diacy}

Lewis (1942) has dealt in some detail with the evolution of sex in flowering plants. From taxonomic evidence he concludes that diœcious species have arisen from both monœcious and hermaphrodite ancestors.

The origin of diøecy from hermaphrodite and more especially from heterostyled plants (class Ia) is of particular interest. Rhamnus catharticus described by Darwin (I877) is a diœcious species in which both sexes have long- and short-styled sub-types. Darlington (1958) emphasised the importance of this case as an illustration of a new breeding system superimposed on a pre-existing system where the old system was heteromorphic incompatibility and the new one is diœcy.

Epigea repens (Darwin, loc. cit.) is a similar case. Again males and females exist in two forms but only the long-styled females have been seen to bear fruit. The short-styled "females" must either be neuter or, if the incompatibility system is still operative, it is possible that they can only be fertilised by pollen from long-styled males. It is obviously 
desirable that pollen grains from the two forms of males in Rhamnus and Epigea should be compared in respect of their growth on long- and short-styled females.

Godley (1955a) has described another interesting situation in Fuchsia procumbens. As in previous examples there are two forms of both male and female but in this species there are also hermaphrodite plants. These are self-compatible and homostyled, a fact which tends to bear out the previous existence of heteromorphic incompatibility in this species.

Drawing once more on Darwin's storehouse of facts, we find that species of Egiphila also illustrate this same interesting sequence of events. A. elata and $A$. mollis are heterostyled hermaphrodites while $A$. obdurata is heterostyled and diœcious. Still further evidence of the transformation of heteromorphic incompatibility into dicey is to be found in the Rubiacex. Psychotria and Cinchona species are described by Darwin as heterostyled hermaphrodites while Burck ( 1885 ) reports that there are other species of both genera in Java which are heterostyled and diœecious like Mussenda and Morinda species. Michella repens may prove to be the most convincing example of all since if Meehan's (1868) observations are confirmed, this species is always heterostyled but dicecious in some districts and hermaphrodite in others.

The genetics of heterostyly and dicecy confirm the link implied by the morphological data. The breeding systems share two common attributes. Firstly, one mating type is homozygous (ss, long-styled plants and $\mathrm{XX}$ females) and the other is heterozygous ( $S s$, shortstyled plants and XY males). Secondly, the contribution of mating type determinants to the next generation is unequal ( $3 \mathrm{X}: \mathrm{IY}$ in dicey and $35 s:$ is in heterostyly. Thus the mating type equilibrium in the population is attained in the same way by the two outbreeding systems. It would only require a change in the relation between $S$ and $s$ in a heterostyled species to create functional dicecy in one step. If dominance were to be replaced by individual action of alleles in Ss styles then the heterozygous plants would act only as males and homozygotes only as females. Alternatively if dominance were to give way to individual action of alleles in the pollen of the heterozygotes they would then be functional females while homozygous plants would be males (fig. I).

There is evidence to suggest that both of these two courses have been followed. In Egiphila, Mussenda and Cinchona it is the long-styled or pin form which is female and the short-styled or thrum form which is male. In Rhamnus lanceolatus and also perhaps in Phlox subulata it is the pin plants which are tending to maleness. In these cases where one form is male and the other female, it must be assumed that the genes controlling sex expression are within, or at least in close proximity, to the differential $S$ and $s$ chromosome segments. The restricted crossingover in the region of the $S$ and $s$ supergenes may indeed initiate or 
hasten the development of non-homologous sex chromosomes. It is obviously important to examine the chromosomes and breeding behaviour of these species to determine which is the heterogametic sex. When the thrum form is male then we expect males to be heterogametic

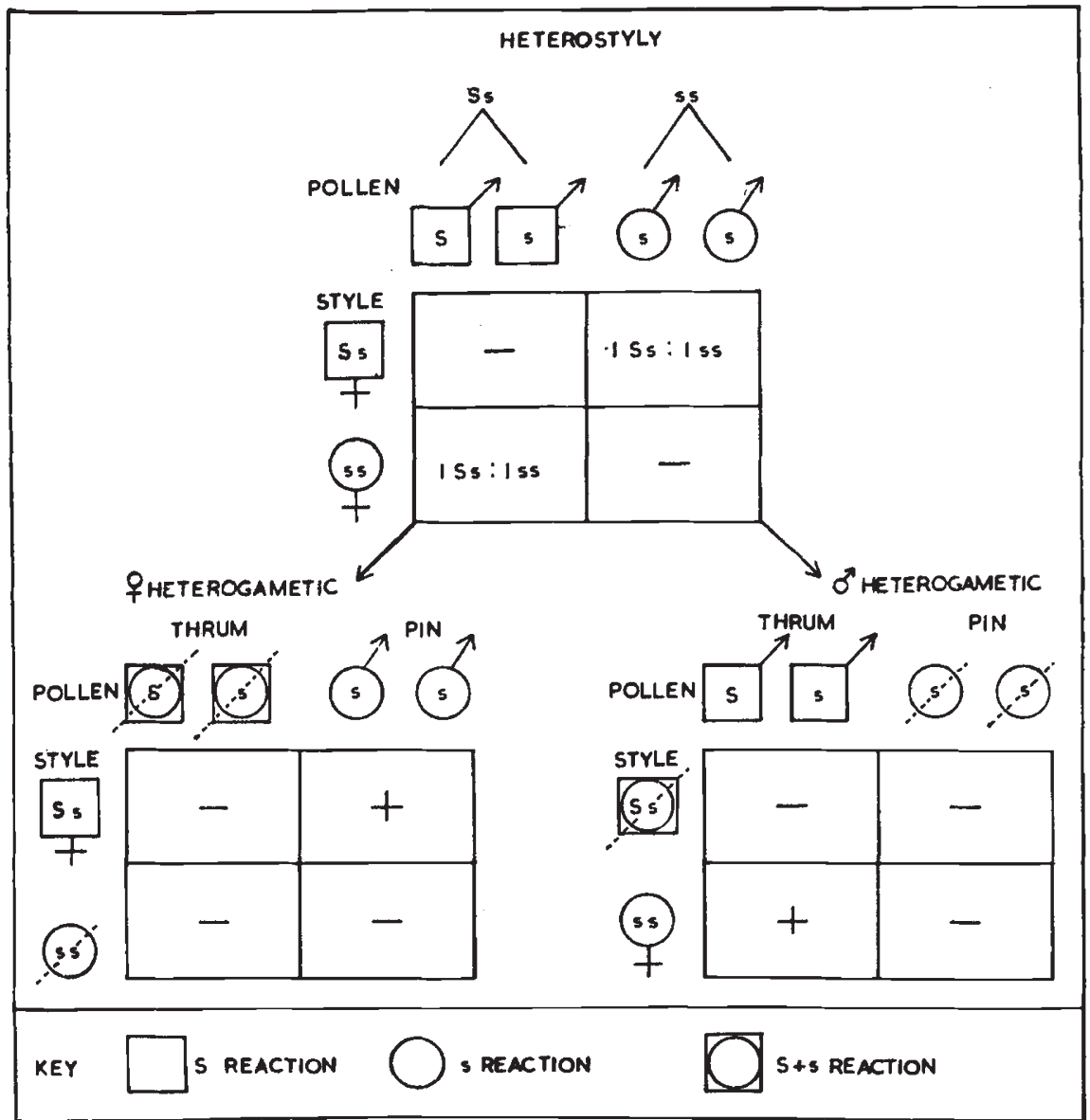

FIG. I.-The evolution of diœey from heterostyly. The change in the breeding system is initiated by a switch from dominance to individual action of the incompatibility alleles in either the pollen or the style of the heterozygous, thrum plants.

on this interpretation but when the thrum form is female then the female should be the heterogametic sex.

In Rhamnus catharticus, Epigea repens and Fuchsia procumbens events have followed a third course. Since there are pin and thrum forms in both sexes, the situation is different in so far as the sex determining genes are not linked with the $S$ and $s$ supergenes.

Despite the interesting relationship between heteromorphic incompatibility and diœcy, taxonomic evidence and genetic considerations imply that the majority of diœcious species have evolved from monœcious ancestors (Lewis, loc. cit.). Clearly there is more opportunity 
for this because monœcy is commoner than heterostyly. It is pertinent to mention in this context that the monœcious genera Hevea, Castanea, Euphorbia (Godley, 1955b), Betula (Hagman, 1963) and Fagus (Nielsen et al., 1954) have self-incompatible species. It is therefore probable that diœcious species derived from monœcious ancestors may also show signs and symptoms of a previous history of incompatibility. It would be of great interest to re-examine such diœcious forms with this possibility in mind.

\section{(ii) The origins of gynodiøey}

Genetically controlled gynodiœcy differs from all other outbreeding systems because, plant for plant, the hermaphrodites in the population contribute three times as many genes to the next generation as the females. This applies not only to the mating-type genes but to all genes. In consequence the females must have a considerable reproductive advantage if they are to occur more frequently than the mutation of the sex-determining gene would allow (Lewis, 1941). A population equilibrium of $\mathrm{I}$ female: $\mathrm{I}$ hermaphrodite can be maintained only by differential fertility or differential fertilisation. Both devices are features of incompatibility systems.

Bateman (1952a) and Lewis and Crowe (1956) have devised two different incompatibility systems which could form a starting point for the evolution of gynodiœecy (fig. 2). There are two mating types in each system and in both it must be assumed that the heterozygous plants are largely self-fertilising and so rendering pollen of the homozygotes superfluous. As a result there will be no selection for pollen fitness in the homozygotes and they will tend in time to become malesterile. In Bateman's scheme (fig. 2A) the equilibrium is attained by selective elimination of $S_{1}$ male gametes in the style of the heterozygote. This is brought about by incompatibility and as a result, half the progeny of the hermaphrodites are always female. The scheme of Lewis and Crowe (fig. 2B) depends on sterilisation of $S_{1}$ eggs of the heterozygote. This too is brought about by incompatibility in the first instance and it reduces the seed output of the hermaphrodites by 50 per cent. The latter scheme comes very close to explaining the behaviour of the gynodiœcious species, Origanum vulgare.

Incompatibility systems with two mating types like those described in the preceding paragraph, have so far always been associated with heteromorphy. It therefore comes as no surprise to find relic heteromorphy in the gynodiœcious species Silene maritima (fig. 3). The styles of the two sexes are equal in length although they are thicker in the flowers of the females. The stamens, however, differ in height. Anthers in the hermaphrodite flowers are on a level with the stigmata when mature while the barren anthers of the female are situated half-way down the corolla tube. Thus the hermaphrodites correspond to long homostyles and as is to be expected they are self-compatible. The females on the other hand correspond to pin plants. The pronounced 


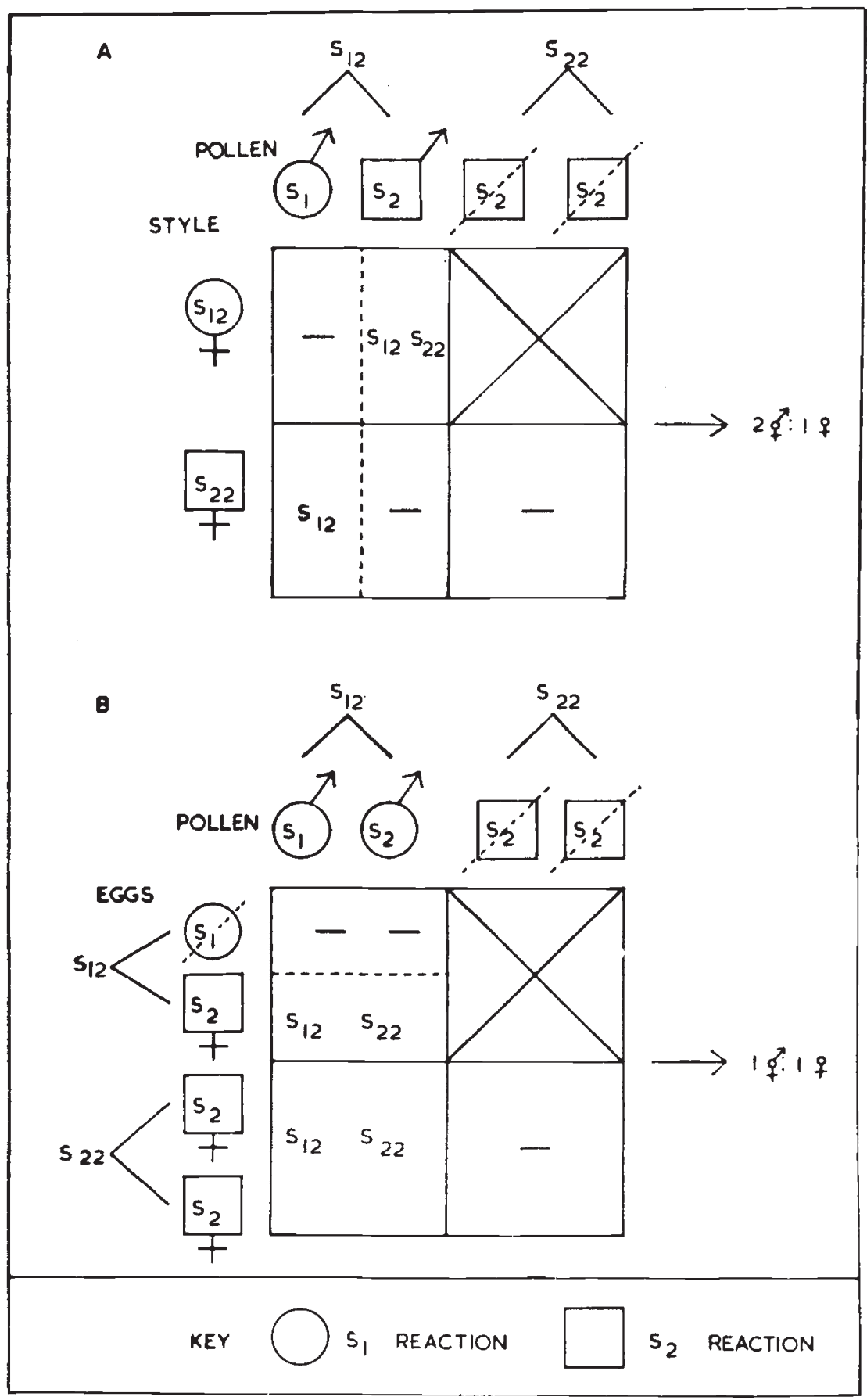

FIG. 2.-The evolution of gynodicecy from incompatibility systems with two alleles.

System $A$ has gametophytic control of mating type in the pollen. In the style $S_{1}$ is dominant to $S_{2}$.

System $B$ has sporophytic control of mating type in the pollen, and $S_{1}$ is dominant to $S_{2}$. There is gametophytic control of mating type in the female gametes. Incompatibility is expressed after fertilisation. 
pollen dimorphism in the hermaphrodites of $S$. maritima confirms this interpretation since it has been shown that some homostyled plants of Primula are heterozygous for the alleles which govern pollen size in their heterostyled ancestors. A slight delay in the activity of these alleles in Silene would cause them to act directly on individual pollen grains so that those carrying the $\mathrm{S}$ allele would be large and those with

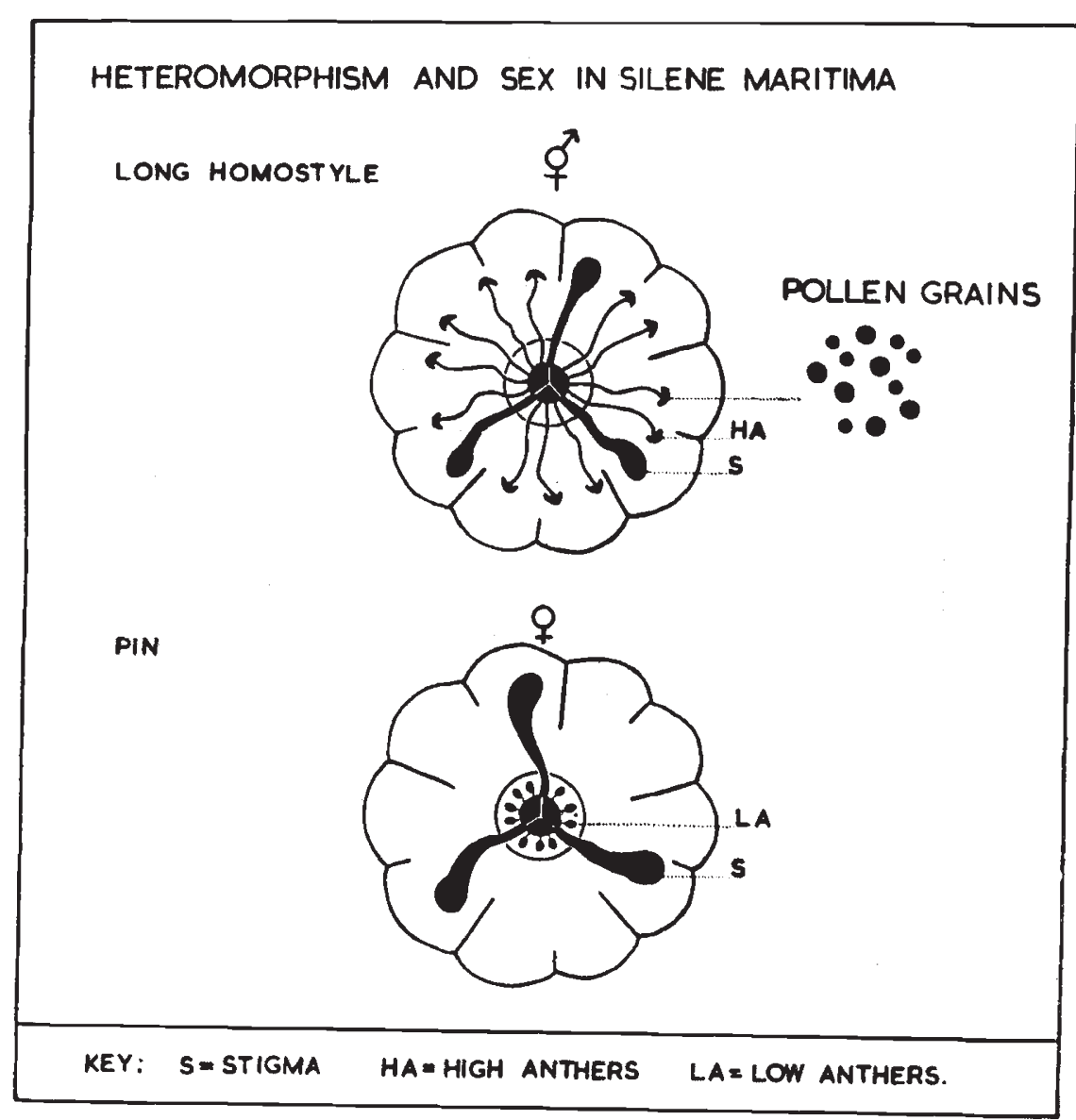

FiG. 3

the s allele, small. Female plants examined so far have failed to produce any pollen so they cannot be compared with the hermaphrodites in this respect.

It is interesting to speculate on the future of Primula vulgaris in those areas where self-compatible homostyles have arisen. At present pin and thrum plants co-exist with the homostyles but Crosby (1949) has remarked on a deficiency of thrum forms in those areas with a high proportion of homostyles. If the homostyles are partially crossfertilised, as claimed by Bodmer (1958), most of the seed will be 
produced from self-pollinated homostyles, from crosses between homostyles and from pin plants pollinated by homostyles. Thus unless thrum plants have a strong selective advantage, the decrease in their numbers will be progressive in each generation. The pollen of pin plants will be functional only so long as thrum forms are present. The smaller the proportion of thrum individuals the closer will the breeding pattern in the population simulate gynodiocy. The pin form will act as female and the homostyle will act as hermaphrodite, just as in Silene. We may in fact be watching gynodiøcy in the making in $P$. vulgaris.

\section{(iii) The origins of heteromorphic incompatibility}

While there are obvious links between heteromorphy, diœcy and gynodiœcy, the origin of heteromorphic incompatibility itself is

TABLE 3

Heteromorphism in Plumbaginacee

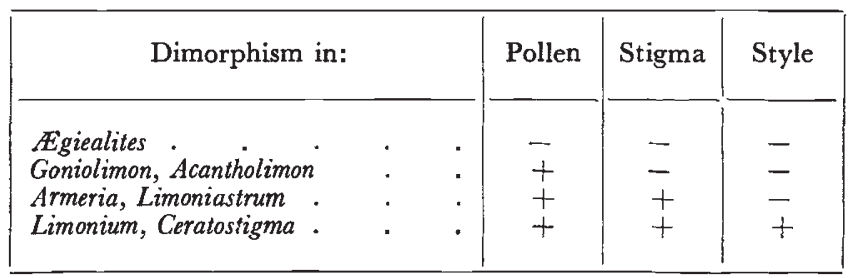

uncertain. From a comparison of the various forms in the Plumbaginaceæ it can be deduced that the immunological difference precedes the morphological differences which apparently build up by stages to culminate in the full array of differential characters found in Primulas (table 3 ).

From the genetic point of view there are close affinities between heteromorphic incompatibility and the homomorphic systems characteristic of the Cruciferæ and Compositæ (class IIc). Both types of system have sporophytic determination of the mating type: in both incompatibility is expressed between the pollen and the style. The fundamental distinction rests in the number of alleles, two in heteromorphic and many in homomorphic species. In the Rubiacex both systems occur but in different genera. Several heteromorphic species in this family have already been mentioned. Amongst the homomorphic species, Galium mollugo has a sporophytic incompatibility system with multiple alleles. Further evidence of association between di- and multiple-allele systems in other families is needed to establish a firm link between them.

It is tempting to suppose that starting with two alleles an incompatibility system can evolve in one of two ways. One possibility is heteromorphic incompatibility. This would depend on the accumulation of alleles producing alternative morphological characters and linked with 
the two incompatibility alleles. The second possibility is homomorphic incompatibility with numerous mating types. This would depend on the evolution of more alleles at the incompatibility locus. The evidence in general does not lend much support to this theory of dichotomous evolution. It is more in line with the view that heteromorphic incompatibility is a degenerate form of homomorphic incompatibility from which it arises by loss of alleles. There are two main reasons why I prefer the second theory:

(i) Many of the heterostyled species are isolated cases in families which are otherwise homomorphic. In most instances some at least of the homomorphic species are known to be self-incompatible. All the evidence suggests that they will prove to have many mating types and many alleles. It is, therefore, reasonable to conclude that the single heteromorphic type is derived from these multi-allelic species rather than vice versa.

(ii) Studies of spontaneous and induced mutations at the incompatibility locus in Primula, Enothera, Trifolium and Prunus have proved unsuccessful in the search for new alleles with new specific mating types. All the mutants were degenerate and gave selfcompatible plants. Evidently then the conditions which gave rise to new alleles in the past are no longer present and cannot easily be restored.

The breeding system in Narcissus could be the exception which proves the rule. $\mathcal{N}$. triandrus, $\mathcal{N}$. reflexus, $\mathcal{N}$. cernuus and $\mathcal{N}$. tazetta are heteromorphic, self-incompatible species. In crosses, compatibility bears no relation to the morphology of the plants and the high percentage of compatible crosses argues that there are numerous mating types. Obviously heteromorphy and incompatibility are two separate systems in this genus and there are two explanations which would fit the facts. Firstly, it may be a case where a typical heteromorphic incompatibility system has lately evolved into a multiple-allelic system. Secondly, it is equally possible that heteromorphy and incompatibility have never been associated systems in Narcissus. The post-fertilisation breakdown of incompatible unions in this species causes ovule wastage and the spatial separation of the anthers and stigma in all plants may simply be a device evolved to reduce self-pollination and the consequent sterilisation of potential seed.*

\section{(iv) The origins of homomorphic incompatibility}

(a) Post-fertilisation incompatibility (class IId). On long term evolutionary grounds it seems likely that incompatibility between male and female gametes is more primitive than incompatibility between pollen-tube and style in the Angiosperms. This applies particularly if incompatibility was inherited from an ancestral type since not only is the gametophytic generation more prominent in lower plants but the

* I am indebted to Dr D. Zohary for suggesting this possibility. 
style is a comparatively recent innovation which singles out Angiosperms from all other phyla.

Reaction between gametes expressed as post-fertilisation breakdown following incompatible pollination is widespread in monocotyledons including Lilium, Freesia, Hemerocallis, Gasteria and Narcissus. It has also been reported in two dicotyledons, Theobroma and Callistemon. In other dicotyledons such as Papaver and Reseda, incompatible pollen tubes grow into the ovary but proof of fertilisation is lacking.

If self-fertilisation is to be completely eliminated with a gametic incompatibility system there must be sporophytic determination of mating type in the gametes of both sexes. In Theobroma cacao, the only example in which the genetics of this type of incompatibility have been worked out in detail, there is one locus with multiple alleles and sporophytic control of mating type in both the pollen and embryo-sacs (Knight and Rogers, I955). As we shall see later, there is reason to believe that sporophytic determination of mating type is recent in origin and has followed gametophytic determination in the evolutionary scale. However, the presence of sporophytic control in Theobroma does not necessarily imply that incompatibility between gametes is also recent in the Angiosperms because the association of primitive and advanced characters in the same species is a common phenomenon. The fact that gametic incompatibility is present in both monocotyledons and dicotyledons suggests that it may even have been present before the bifurcation of these two great lines of decent, which would make it an extremely early outbreeding system in the Angiosperms.

Incompatibility of this type has the inherent disadvantage that if incompatible pollen is the first to alight on the stigma, some if not all the availablefof the available ovules will be sterilised. This may explain why the system has been reported only in perrenials with efficient methods of vegetative reproduction. In short-lived annuals the loss of potential seeds would be more dangerous and it therefore seems a logical conclusion that incompatibility between pollen and style which does not spoil ovules was first evolved in association with the annual habit.

(b) Gametophytic and sporophytic incompatibility (classes IIa and IIc). The two commonest forms of homomorphic incompatibility in which the incompatibility reaction is expressed in the style are, with the exception of Tradescantia, so far, confined to the dicotyledons. We have already observed that one or other system is characteristic of a family (table I) but it is equally important that widely separated families have identical systems. The gametophytic systems in the Onagraceæ, Leguminoseæ, Rosaceæ, Solanaceæ, Scrophulariaceæ and Malvaceæ are alike. The first three families have even been shown to produce similar mutations of the incompatibility gene. Sporophytic incompatibility systems in the Compositæ and Gruciferæ are also identical down to the smallest details such as the characteristically early inhibition of incompatible pollen. Such close parallels in divergent 
families must surely mean that the systems once established have been handed down unchanged. Indeed they show greater stability than most of the variables which are the conventional bases of classification.

Although a considerable number of examples of both sporophytic and gametophytic incompatibility are known, there are so many families and even whole orders with uncharted outbreeding systems that a distribution map is of no value in determining the relationship of these two systems. This problem, however, can be overcome by the indirect approach of seeking correlations between the type of breeding system and other characters of phylogenetic significance. Brewbaker's (1957) observation of a correlation between the type of pollen development and the type of incompatibility is a successful example of this kind of approach. Bi-nucleate pollen grains are the rule in families with gametophytic incompatibility and tri-nucleate pollen grains in families with sporophytic incompatibility. A survey by Pandey (196oa) reveals that binucleate pollen is older than tri-nucleate pollen in Angiosperm evolution and that the switch from bi- to tri-nucleate pollen is irreversible. By inference it follows that the gametophytic incompatibility systems are older than the sporophytic systems.

The main difference between the two systems is essentially the result of a difference in the time at which the mating type specificity is imposed on the pollen. If it is imposed on the diploid pollen mother cells or earlier, then there is sporophytic control of pollen specificity. If it imposed on the haploid pollen grain, then the control is gametophytic. The other important difference is the fact that in gametophytic incompatibility there is always individual action of alleles in the style while in sporophytic systems some pairs of alleles exhibit dominance.

It is possible to make certain assertions about the sequence of events involved in a change-over from gametophytic to sporophytic incompatibility. If the first step was the expression of dominance between alleles in the style, this would lead to a breakdown of the outbreeding system since the style would then exhibit one specificity instead of two as before and would therefore inhibit only half the pollen from the same plant. If, however, sporophytic control of the pollen came first there need be no self-compatibility. Outbreeding would persist provided there was dominance or individual action between alleles in the pollen mother cells. It is clear from the behaviour of pollen grains in induced tetraploids of Enothera and other genera that many pairs of alleles exhibit dominance or individual action as primary properties (Lewis, 1947). There are also examples of competition between alleles in the pollen of tetraploids. Competition in pollen mother cells of diploids would lead to self-compatibility but selection acting against any alleles displaying competitive interaction would prevent any permanent breakdown in the outbreeding system.

That the changes in the pollen and the style are sequential rather than simultaneous during the switch to sporophytic control of mating type is purely conjecture. However, it would account for the frequent 
differences in the dominance relations of the same pair of alleles in the organs of the two sexes. It would also explain the fact that in some species like Parthenium (Gerstel, I 950), dominance between alleles in the pollen is common but in the style most pairs of alleles show individual action as they do in gametophytic systems.

(c) Two-locus incompatibility (class IIb). The last type of homomorphic incompatibility is that with multiple alleles at two loci. This is present in grasses (Lundquist, I956; Hayman, I 956) and in at least two members of the Solanaceæ, Solanum pinnatisectum and Physalis ixocarpa (Pandey, I957, I96ob). Pandey (I962) has discussed the origin of these systems in Solanum and Physalis and concludes that the two-locus system is a secondary derivative of the one-locus system common in the Solanaceæ (class IIa). He suggests that the second locus is a duplication arising by a structural change in the chromosomes.

The introduction of a second locus could initially lead to selfcompatibility as a result of competitive interaction between alleles at different loci. If inbreeding is of advantage to the species the additional locus will probably become established as an integral part of the breeding mechanism. Usually, however, outbreeding has been restored in one of three ways.

(i) In $S$. pinnatisectum, one locus has mutated.

(ii) In $P$. ixocarpa, alleles showing competitive interaction have been eliminated.

(iii) In the Graminea, the problem of the co-existence of two series of alleles has been solved by a division of labour between alleles at different loci. In this family, a pollen grain with a mutated nonspecific allele at one locus, for example $\mathrm{S}_{1} \mathrm{Z}_{f}$, will grow on all styles including those in which $\mathrm{S}_{1}$ is present. Evidently two alleles, one from each series, are required to produce one specificity, for example $S_{1} Z_{1}$. Thus the $\mathrm{S}$ and $\mathrm{Z}$ loci are complementary and not competitive like duplicated S loci. Nevertheless, it is probable that the two loci in grasses were initially duplicate loci which have in time become differentiated (Lundquist, I963). Lewis (I963) proposes that the products of $\mathrm{S}$ and $\mathrm{Z}$ form a dimer like the $\alpha$ and $\beta$ haemoglobin chains.

\section{SELF-COMPATIBLE SPECIES}

In self-compatible plants evidence of extinct outbreeding systems comes from a variety of sources.

(i) Many species of cultivated plants have been selected for selfcompatibility but are self-incompatible in nature. Antirrhinum majus, Enothera trichocalyx, Papaver alpinum and Nicotiana langsdorfii are such cases.

(ii) No self-incompatible races of wallflower have yet been reported even in nature but Bateman ( $195^{6}$ ) has demonstrated that in cultivated varieties, cross pollen still grows faster than self pollen in the style.

(iii) One of the most remarkable survivals of a past outbreeding 
system occurs in Enothera biennis. This is a structurally heterozygous species forming a ring of fourteen chromosomes at meiosis. It is regularly self-fertilising. Steiner (I96I) discovered that the balanced lethal system depended on an incompatibility allele in the pollen and style. When different races are crossed new hybrids are produced in which pollen complexes with alleles not present in the foreign styles are able to achieve fertilisation and self-incompatibility is restored in some of the offspring.

In all these examples self-compatibility has obviously been acquired recently. But in the following species, self-compatibility must have existed for a longer time.

(i) Oxalis sensitiva has cleistogamous flowers but the heteromorphy associated with incompatibility in the closely related $O$. vivaldiana still persists.

(ii) Passiflora suberosa is self-compatible with small, green, inconspicuous flowers, a dramatic contrast with the large, brightly coloured flowers of the self-incompatible Passifloras, yet all the elaborate floral structures designed to attract insect cross-pollinators are still present in miniature (Lewis, 1956).

(iii) Lycopersicum esculentum is self-compatible even in wild populations (Rick, I950) and as is to be expected of a long term inbreeder, shows neither heterosis nor inbreeding depression. Similarly, Antirrhinum orontium has no self-incompatible races and the small flowers enforce self-pollination. However, both $L$. esculentum and $A$. orontium are closely related to self-incompatible species.

The differences in these inbreeding species which distinguish them from outbreeders in the same genus must have taken time to accumulate. Evidently then inbreeders fall into two classes, those of recent origin, Sf, which include experimentally induced inbreeders, and those of ancient origin, SF.

Species which are classified as Sf or SF on taxonomic or morphological evidence also have distinguishing properties which are revealed in crosses with self-compatible individuals of another species (Lewis and Crowe, I958). Thus a combination of different techniques has revealed symptoms of extinct outbreeding systems in a wide range of selfcompatible species.

\section{THE PHYLOGENY OF OUTBREEDING SYSTEMS}

This survey has shown that mechanisms which appear to be poles apart sometimes prove on close inspection to share a common evolutionary lineage. The emerging pattern of these unsuspected relationships is already sufficiently clear to provide the basis for a phylogenetic arrangement of the outbreeding systems in the Angiosperms (fig. 4).

I would propose as a starting point in this scheme a system which has not so far been observed. It would be difficult to detect since it 
does not completely exclude self-fertilisation but merely bars homozygosity at the incompatibility locus and causes higher fertility in matings between unrelated individuals. I assume the existence of this original system because it combines inter-gametic incompatibility,

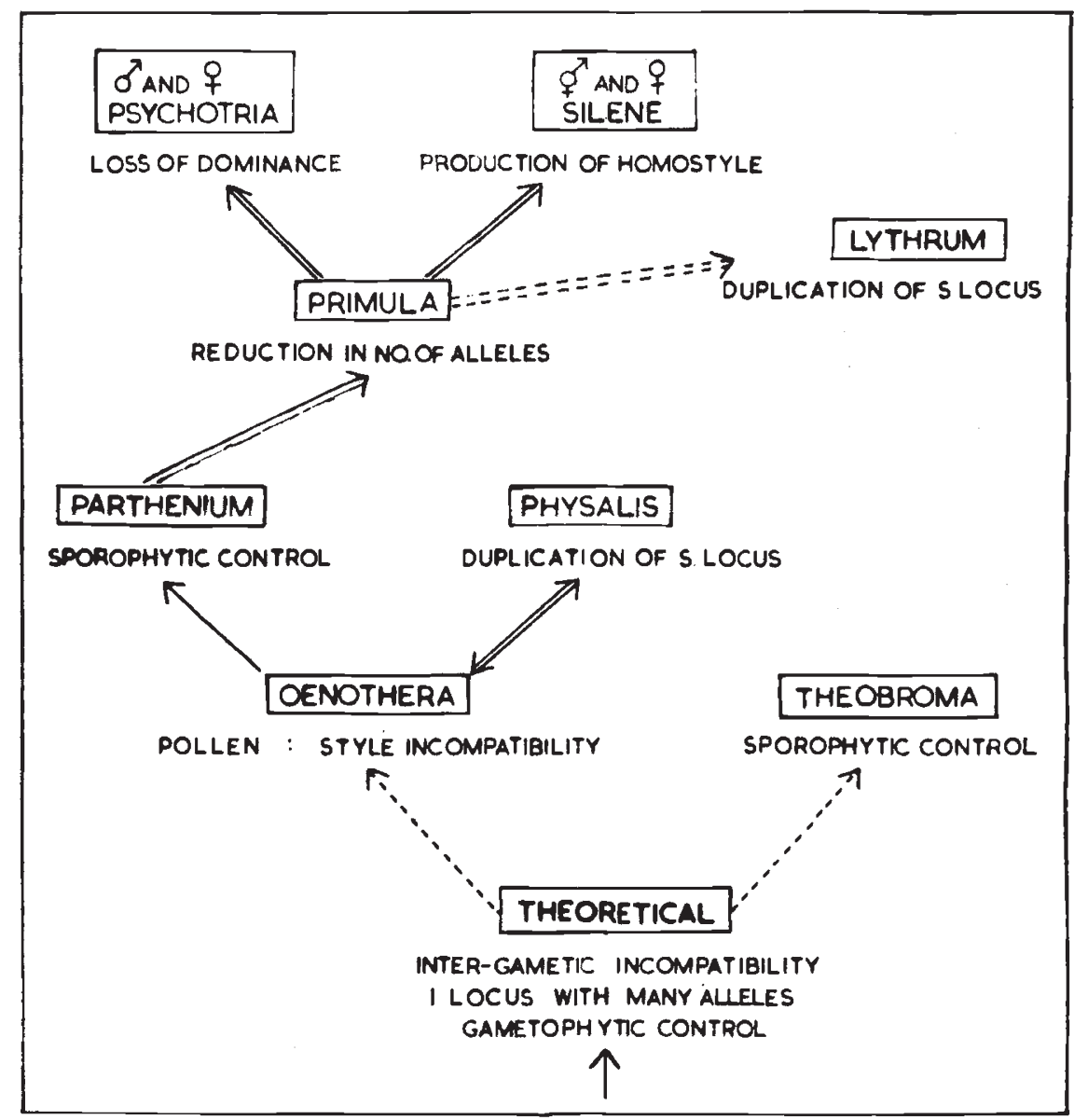

FIG. 4.-The phylogenetic arrangement of eight outbreeding systems in the Angiosperms.

Key: — links between living systems, - - - - links which have not yet been demonstrated, $=$ steps which have occurred more than once.

The genera are typical examples of the various outbreeding systems. No living representatives of the original system at the bottom of the figure have been found.

gametophytic control of mating type and a single locus with multiple alleles, all features which on existing evidence were present early in the evolution of the Angiosperms.

A switch from gametophytic to sporophytic control of the mating type would convert the original system to the secondary system found in Theobroma (class IId). Alternatively, if the production of the incompatibility substance was transferred from the female gametes to the style, then the secondary system would correspond to that of Enothera (class IIa). 
From this point onwards developments are directly substantiated by living systems.

(i) Firstly, the behaviour of those species with two loci like Secale and Physalis (class IIb) and their association with one-locus types in the Solanaceæ leave little doubt that they have been produced by the duplication of the $\mathrm{S}$ locus. The mating behaviour of some species of Solanum suggests that this step may be reversible.

(ii) Secondly, the correlation between pollen development and type of incompatibility together with the distribution of families with bi- and tri-nucleate pollen grains indicates that the CEnothera system can also give rise to the type found in Parthenium (class IIc). This step involves a change from gametophytic to sporophytic control of mating type.

(iii) Thirdly, heteromorphic incompatibility as represented in Primula (class Ia) has close genetic affinities with the Parthenium system and both systems co-exist in the Rubiacex. The sporadic distribution of heteromorphic incompatibility suggests that the two-allele systems have been derived from types with multiple alleles in the Angiosperms rather than vice versa.

(iv) Heteromorphic incompatibility can in turn evolve into diœcy as in Psychotria and Rhamnus and into gynodiøcy as in Silene.

(v) There is no direct evidence to show how the more complex heteromorphic incompatibility as exemplified in Lythrum (class Ib) has arisen. Many species of both Lythrum and Oxalis are tristylic with two incompatibility loci. There have also been reports of dimorphic species in both genera. Such reports have not yet been confirmed but if they are correct, then it may be supposed that these species have only one incompatibility locus. It is likely, therefore, that the two-locus system of Lythrum has arisen by a duplication of the $\mathrm{S}$ locus.

This evolutionary arrangement of the breeding systems fits all the available facts. Although self-compatibility has not been represented in fig. 4 it is known to evolve by a process of degradation from all outbreeding systems except diœcy.

\section{DISCUSSION}

Darlington (1963) has described the evolutionary changes in the breeding system associated with the origins of species. In this context he introduced the concept of an "ideal ancestor". This type is diploid with sexual reproduction and free gene exchange as a result of outbreeding and distributed chiasmata. In the evolutionary sense ideal ancestral populations are totipotent. They can give rise to all kinds of species and all kinds of genetic systems. They do so usually by restricting gene exchange; by hybridisation, polyploidy, localisation of chiasmata or inbreeding.

These restrictive practices are normally irreversible and cumulative in their effects. The evolutionary potentialities of the species they create are permanently canalised and give rise only to those types with still greater barriers to gene exchange. Evidently deviation from the 
ideal ancestral type produces a sideline which is for ever cut off from the mainsteam of evolution. Ideal ancestors must therefore leave two kinds of decendants. Not only do they leave those species with strictly limited capacity for further change but they must also perpetuate their own kind. Evolution depends on an uninterrupted flow of ideal ancestral types and they and they alone can ensure that unbroken succession.

If we accept the principle that ideal ancestors do not arise de novo but are decended from one another, it follows that they must all trace back to a common stock. Now, for the first time, there is evidence to show that this is so. Their common ancestry is revealed by continuity in the genetic basis of their outbreeding systems. On a small scale a detailed comparative study has shown the different breeding systems in the Angiosperms to be variations of one and the same incompatibility system.

There is no reason to suppose that the Angiosperms are unique in this respect. In the Fungi, the other phylum in which the breeding systems have been extensively studied, the situation is essentially the same. In this group the simplest of all incompatibility systems is found in many Phycomycetes and Ascomycetes. It has one locus and two alleles and may be taken as the original type of incompatibility in Fungi. In the Basidiomycetes there are more complex systems of two kinds:-

(i) There are incompatibility systems with multiple alleles at one locus, the so-called bipolar systems. These may be derived from the original system by the evolution of more alleles.

(ii) There are tetrapolar systems with two loci each with multiple alleles.

Sometimes both of these secondary systems are present in the same genus as for instance in Coprinus. The incompatibility loci in Coprinus and in many other Basidiomycetes have a complex structure and in the tetrapolar systems, the two loci have been shown to have the same structure in a number of cases. Therefore the second locus has evidently arisen by a duplication.

The continuity in the genetic basis of outbreeding that exists within a phylum must also extend to different phyla. Major evolutionary changes destined to initiate a new phylum can only arise from an outbreeding stock. The new, untried prototypes must preserve their outbreeding habit for only by so doing can they produce workable combinations of genes for their own survival and the necessary diversity of new forms in their decendants. It is most unlikely that a new outbreeding system will evolve amongst the small numbers of individuals present at the origin of a new phylum. There is in fact no need to postulate such an improbable event when individuals have outbreeding ancestors because we know now that the genetic basis of outbreeding can be inherited. 
The presence of incompatibility in the fern, Pteridium, in the Gymnosperm, Larix, as well as so generally in Angiosperms shows that the system has accompanied the evolution of diploid organisms. Its presence in Ascomycetes and Basidiomycetes shows that it has also been associated with the evolution of the dikaryon. Incompatibility is also found in the most primitive sexual cycles where meiosis immediately follows the fusion of gametic nuclei as for example in the desmid, Cosmarium botrytis and in Mucor. Thus incompatibility spans the entire plant kingdom. It therefore seems most probable that the genetic basis of incompatibility has been a continuous factor in the evolution of plants.

\section{SUMMARY}

I. This paper deals with two fundamental questions concerning the evolution of breeding systems in plants:-

(i) Is the basic immunological reaction of incompatibility the common source from which all types of breeding system have evolved?

(ii) Is the unbroken succession of outbreeding populations on which evolution depends maintained by continuity in the genetic basis of incompatibility?

2. A comparative study of breeding systems in related individuals within species, genera, families and still larger groups in the Angiosperms shows how breeding systems of nine types can evolve from one another in the following directions:-

(i) Incompatibility systems with one controlling locus give rise to those with two loci by duplication.

(ii) Incompatibility systems with multiple alleles are shown to give rise to those with few alleles and do so more commonly than the reverse.

(iii) Incompatibility systems with gametophytic control of mating type are shown to give rise to those with sporophytic control by the familiar principle of shift in the time of gene action.

(iv) Incompatibility between male and female gametes probably gives rise to incompatibility between pollen tube and style.

(v) Hermaphrodites are shown to make use of their incompatibility loci as a means of initiating diœcy and gynodiœcy.

(vi) All incompatibility systems are shown to break down giving rise to self-compatibility and inbreeding.

3. Based on these observations a phylogenetic arrangement of breeding systems in the Angiosperms is presented (fig. 4). The evidence is consistent with the view that the first Angiosperms were hermaphrodites with a primitive, ancestral incompatibility system and that all other breeding systems in the group have evolved by stages from the primitive type.

4. The various incompatibility systems in the fungi are shown to be related and to evolve from one another by the same means.

5. It is shown how the continuity in the genetic basis of incompatibility existing within phyla must extend to different phyla. It 
is present in Algx, Pteridophytes and Gymnosperms as well as in Fungi and Angiosperms. It is therefore associated with haploid, diploid and dikaryotic organisms representing all stages in the evolution of plants.

6. It is therefore concluded that the genetic basis of incompatibility has been continuous in the mainstream of evolution of plants.

\section{REFERENCES}

BAKER, H. G. 1954. Dimorphism and incompatibility in the plumbaginacex. Proc. 8th Int. Cong. Bot., Io, I33-1 34 .

BAKER, H. G. Ig62. Heterostyly in the Connaraceæ with special reference to Byrsocarpus coccineus. Bot. Gaz., 123, 206-211.

ватеman, A. J. 1952a. Self-incompatibility systems in Angiosperms. Heredity, 6, 285-310.

bateman, A. J. 1952b. Trimorphism and incompatibility in Narcissus. Nature, 170,496 .

bateman, A. J. 1956. Crytic self-incompatibility in the wallflower: Cheiranthus cheiri L. Heredity, 10, 257-261.

BAUR, E. 1932. Artumgrenzung und Artbildung in der gattung Antirrhinum. Z.I.A.V., 63, 256-303.

Bodmer, w. F. 1958. Natural crossing between homostyle plants of Primula vulgaris. Heredity, $12,363-370$.

BREWBAKER, J. L. I957. Pollen cytology and incompatibility systems in plants. 7. Hered., 48, $271-277$.

BURCK, м. w. I885. Sur l'organisation florale chez quelques Rubiacées. Ann. Fard. Bot. Buitenzorg, 3, 105-1 18.

CROSBY, J. L. 1949. Selection of an unfavourable gene complex. Evolution, 3, 212-230.

Darlington, C. D. 1958. Evolution of Genetic Systems. 2nd ed. Oliver and Boyd, London and Edinburgh.

Darlington, C. D. 1963. Chromosome Botany. 2nd ed. Allen and Unwin, London. DARWIN, c. 1876. Cross and Self-fertilization of Plants. John Murray, London.

DARwin, c. 1877. The Different Forms of Flowers on Plants of the same Species. John Murray, London.

Dowrick, V. P. J. 1956. Heterostyly and homostyly in Primula obconica. Heredity, IO, $219-236$.

EAst, в. м. I940. The distribution of self-sterility in the flowering plants. Proc. Amer. Phil. Soc., 82, 449-518.

FAGERLIND, F. 1937. Embryologische, Zytologische und Bestäubungs experimentelle Studien in der Familie Rubiaceæ nact Bemerkungen über einige Polyploiditäts Probleme. Act. Hort. Berg., II, 195.

FRYXELI, P. A. 1957. Mode of reproduction of higher plants. Biol. Rev., 23, I35-233.

GERSTEL, D. U. 1950. Self-incompatibility studies in Guayule. II. Inheritance. Genetics, 35, 482-506.

GodLEY, E. J. I955a. Breeding systems in New Zeland plants. 1. Fuchsia. Ann. Bot. N.S., 19, 549-559.

GodLEy, E. J. I955b. Monœcy and incompatibility. Nature, I76, I I76-1 I 77 .

hagman, м. 1963. Incompatibility in Betula verrucosa Ehrh. and Betula pubescens Ehrh. Proc. IIth Int. Cong. Gen., I, 211.

hayman, D. L. 1956. The genetic control of incompatibility in Phalaris cœrulescens. Austral. F. Biol. Sci., 9, 32 1-331.

hutchinson, J. 1926. Families of Flowering Plants. Macmillan, London. 
KNIGHT, R., AND ROGERS, H. H. 1955. Incompatibility in Theobroma cacao. Heredity, 9, 69-77.

LEWIS, D. 194I. Male sterility in natural populations of hermaphrodite plants. New Phyt., 40, 56-63.

LEWIS, D. 1942. The evolution of sex in flowering plants. Biol. Rev., 17, 46-67.

LEWIS, D. 1947. Competition and dominance of incompatibility alleles in diploid pollen. Heredity, $1,85-108$.

LEWIS, D. 1956. Genetics and plant breeding. Brookhaven Sym. Biol., 9, 89-10o.

LEWIS, D. 1963. Incompatibility-a protein dimer hypothesis. Proc. I Ith Int. Cong. Gen., 2 (in press).

LEWIS, D., AND CROWE, L. K. 1956. Genetics and evolution of gynodicecy. Evolution, IO, $115^{-1} 25$.

LEWIS, D., AND CROWE, L. K. 1958. Unilateral incompatibility in flowering plants. Heredity, 12, 233-256.

LUNDQUist, A. 1956. Self-incompatibility in rye. I. Genetic control in the diploid. Hereditas, 42, 293-348.

Lundeurst, A. 1963. The genetics of incompatibility, Proc. 11th Int. Cong. Gen., 2 (in press).

MEEHAN, H. I868. (Quoted by Darwin in Forms of Flowers.)

NIELSEN, P. C., AND SCHAFFALITZKY DE MUCKADELI, M. 1954. Flower observations and controlled pollinations in Fagus. Zeits. Forstgen. $v$ Forstsflanzen, 3, 6-1 7 .

PANDY, K. K. 1957. Genetics of incompatibility in Physalis ixocarpa, Brot. A new system. Amer. 7. Bot., 44, 876-887.

PANDY, K. K. I960a. Evolution of gametophytic and sporophytic systems of selfincompatibility in Angiosperms. Evolution, 14, 98-1 15.

PANDY, K. K. 1960 b. Self-incompatibility in two Mexican species of Solanum. Nature, $185,483-484$.

PANDY, K. K. 1962. Genetics of incompatibility behaviour in the Mexican Solanum species, S. pinnatisectum. Zeit f. Vererbung., 93, 378-388.

PIATNITsky, s. s. 1934. Experiments with self-pollination of Larix, Acer and Quercus. U.S. For. Serv. Translation, 290.

RICK, C. M. I950. Pollination relations of Lycopersicum esculeutum in native and foreign regions. Evolution, 4, $110-122$.

STARR, R. C. 1954. Inheritance of mating type and a lethal factor in Cosmarium botrytis var. Subtumidum Wittr. Proc. Nat. Acad. Sci. Washington, 4o, 1060-1063.

STEINER, E. I96r. Incompatibility in the complex heterozygotes of Enothera. Genetics, 46 , 30 I-315.

Whitehouse, H. L. к. 1949. Multiple allelomorph heterothallism in the Fungi. New Phyt., 48, 21 2-244.

WhItehouse, H. L. K. I950. Multiple allelomorph incompatibility of pollen and style in the evolution of the Angiosperms. Ann. Bot. N.S., 14, 199-2 16.

WILKIE, D. 1956. Incompatibility in bracken. Heredity, Io, 247-256.

YAMPOLSKY, C., AND YAMPOLSKY, H. 1922. Distribution of sex forms in the phanerogamic flora. Bibl. Genet., 3, I-62. 